\title{
Vaquerosella perrillatae sp. nov.: A Miocene species of Echinarachniidae (Echinodermata: Clypeasteroida) from Baja California Sur, Mexico
}

\author{
Alejandra Martínez-Melo and Jesús Alvarado-Ortega
}

\begin{abstract}
The North American Pacific Coast represents an area with a rich fossil record of Neogene scutelliforms. Here, a new species of echinarachnid sand dollar is described and named as Vaquerosella perrillatae sp. nov., based on 21 well-preserved specimens from the Miocene marine deposits of the San Ignacio Formation, Baja California Sur, western Mexico. The skeleton of this species is characterized by the presence of deep postero-lateral notches and a straight posterior margin. This, the first finding of Vaquerosella in Mexico, represents an important contribution to the knowledge of taxonomical and morphological diversity of this extinct genus and confirms that during the Miocene this had a wider geographical distribution towards the southern region of the Pacific coasts of North America.
\end{abstract}

Alejandra Martinez-Melo. UMR 7207, Centre de recherche en Paléontologie- Paris, Museum National d'Histoire Naturelle. 8 rue Buffon, CP 38, 75005 Paris, France. a.mtz.melo@gmail.com Jesus Alvarado-Ortega. Departamento de Paleontología, Instituto de Geología, Universidad Nacional Autónoma de México. Ciudad Universitaria. C.P. 04510, Ciudad de México, México. alvarado@geologia.unam.mx

Keywords: Echinoidea; Clypeasteroida; new species; San Ignacio Formation; Baja California Sur; Miocene Submission: 23 October 2019. Acceptance: 16 March 2020.

\section{INTRODUCTION}

Recently, during the review of the Baja California Sur Section at the Colección Nacional de Pale- ontología (CNP), housed at the Instituto de Geología (IGM) of Universidad Nacional Autónoma de México (UNAM), we discovered large unprepared samples of sandy calcareous rocks from the

http://zoobank.org/5B28523A-C6D3-4AE1-AC2F-FF789BF99E4A

Martínez-Melo, Alejandra and Alvarado-Ortega, Jesús. 2020. Vaquerosella perrillatae sp. nov.: A Miocene species of Echinarachniidae (Echinodermata: Clypeasteroida) from Baja California Sur, Mexico. Palaeontologia Electronica, 23(1):a14. https:// doi.org/10.26879/1040

palaeo-electronica.org/content/2020/2983-new-vaquerosella-from-mexico

Copyright: March 2020 Paleontological Society.

This is an open access article distributed under the terms of Attribution-NonCommercial-ShareAlike 4.0 International (CC BY-NC-SA 4.0 ), which permits users to copy and redistribute the material in any medium or format, provided it is not used for commercial purposes and the original author and source are credited, with indications if any changes are made. creativecommons.org/licenses/by-nc-sa/4.0/ 
San Ignacio Formation with numerous clypeasteroids, bivalves, and gastropods included, strongly dissolved, and mostly recrystallized. These rock samples were collected in July 1979 by Shelton P. Applegate and Luis Espinosa Arrubarrena, in two marine localities near San Ignacio town, Mulegé Municipality, Baja California Sur, Mexico. After the preparation of these, complete and fragmented specimens of well-preserved clypeasteroids were discovered. Preliminarily, we reported these fossils in the National Paleontological Congress of Mexico as representatives of the genus Abertella Durham, 1953, which gives the name to family Abertellidae (Martínez-Melo and Alvarado-Ortega, 2019); however, orally in the same event we modified our taxonomic approach and proved that these fossils represent a new species of Vaquerosella Durham, 1955 , that is a member of the family Echinarachniidae.

The family Echinarachniidae, named by Lambert (in Lambert and Thiery, 1914), is a diverse group of sand dollar ranging from the Middle Eocene to the present. This family consists of numerous extinct species, recovered in fossiliferous strata deposited under the Pacific domain along North America and Northeast Asia coasts. The single living species of this family is Echinarachnius parma (Lamarck, 1816), a common inhabitant of shallow and interstitial marine zones along the Pacific and Atlantic of North America as well as the northwestern Pacific of Asia, from Aleutian Islands to Japan. Smith and Kroh (2011) stated that this family consists of seven valid genera: 1) Faassia Schmidt, 1971 (in Shmidt and Sinyelnikova, 1971), represented by a single species from the Late Miocene deposits of western Kamchatka Peninsula, eastern Rusia; 2) Proescutella Pomel, 1883, represented only by a single species recovered in the Middle Eocene sediments at Loire Atlantique (before Loire inferieur) and Vendee, northwestern France; 3) Pseudastrodapsis Durham, 1953, that includes four Miocene-Pliocene species from Japan and the Kamchatka Peninsula, Russia (Smith and Kroh, 2011); 4) Astrodapsis Conrad, 1856, includes at least 13 extinct species from Miocene to Pliocene deposits of Pacific coast of California, USA (Conrad, 1856; Pack, 1909; Kew, 1920; Hall, 1962); 5) Echinarachnius Gray, 1825, represented by six Miocene to Pliocene species recovered in different sites of Japan (Nisiyama and Hashimoto, 1950; Morishita, 1953; Nisiyama, 1968); four species present in Middle Miocene and Pliocene deposits of Alaska, USA (Durham, 1957; Wagner, 1974); one species from Middle Miocene deposits of California (Kew, 1920), and the single Pliocene to Recent species present in both sides of North America, in the Pacific realm of Alaska and the Atlantic costs of Massachusetts, USA (Hall, 1962), and in the Northwest Pacific from Aleutian Islands via Kamchatka to Japan (Mortensen, 1948); 6) Scutellaster Cragin, 1895, from the Oligocene to Pleistocene along the Pacific coasts of North America, from Alaska to California (Wagner, 1974); and 7) Vaquerosella Durham, 1955, previously known by six nominal species from deposits of the Temblor and Vaqueros formations, in California, USA (Durham, 1955; Adegoke, 1969; among others).

The aim of this paper is to name and describe the skeletal anatomy of a new species of the genus Vaquerosella from Mexico, based on specimens from the Miocene marine deposits of the San Ignacio Formation, recovered in paleontological sites near San Ignacio town, Baja California Sur, Mexico. This is the first report of Vaquerosella out of California, USA, and the second record of the family Echinarachniidae from Baja California, Mexico, after, Astrodapsis bajasurensis Squires and Demetrion, 1993, previously collected in deposits belonging to the Isidro Formation, in the middle part of this Mexican State (Martínez-Melo and AlvaradoOrtega, 2019).

\section{GEOLOGICAL SETTING}

The fossils described here were collected from two localities belonging to the Mulegé Municipality, northern region of Baja California Sur, Mexico. These localities are named as the Arroyo San Ignacio (San Ignacio Creek) and the Arroyo Nacho (Nacho Creek), catalogued into the CNP as IGMloc 248 and IGM-loc 265, respectively. The site IGM-loc 248 is located at the coordinates at $27^{\circ} 15^{\prime} 21.00^{\prime \prime} \mathrm{N}$ and $112^{\circ} 51^{\prime} 18.00^{\prime \prime} \mathrm{W}$, about $5.5 \mathrm{~km}$ southeastward from San Ignacio town, while site IGM-loc 265 is at $27^{\circ} 09^{\prime} 22.00 " \mathrm{~N}$ and $113^{\circ} 01^{\prime} 52.00 " \mathrm{~W}$ and about $21 \mathrm{~km}$ southwestward from the same town (Figure 1). Both paleontological sites represent outcrops of marine sediments identifiable as part of the San Ignacio Formation (see Romero-Rojas et al., 1997).

In the San Ignacio region, sedimentary and volcanic rocks are exposed (Figure 1). Among these, the oldest geological unit corresponds to Eocene marine sequence of yellowish to grayish laminated fine arkoses interstratified with siltstones, diatomites, and some layers of silica lutites deposited under bathyal conditions, which were named as the Bateque Formation by Mina-Uhink 


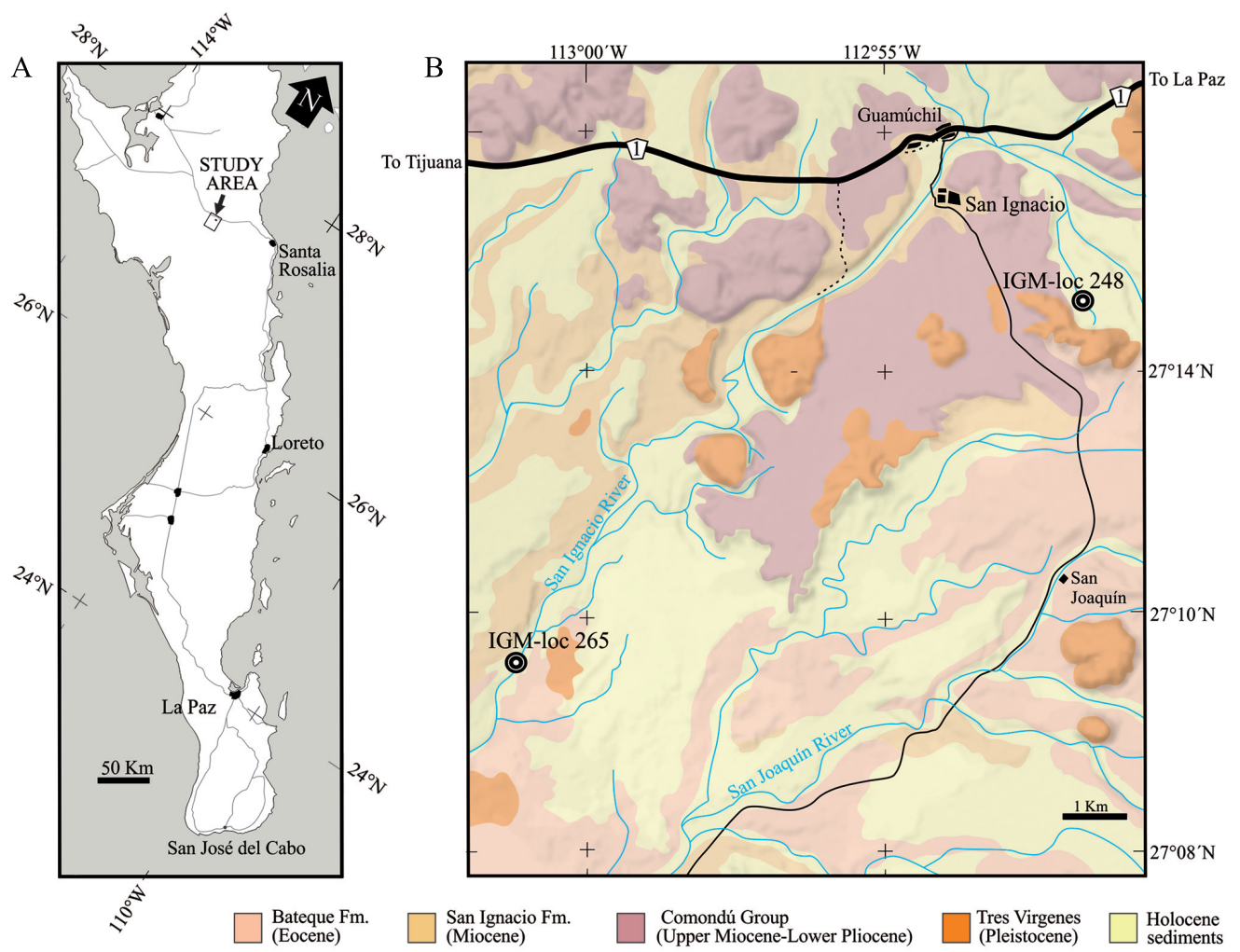

FIGURE 1. Map of the San Ignacio region within the Baja California Peninsula, Mexico, source of the fossil specimens of Vaquerosella referred in this manuscript. A, general view of the lower part of the Baja California Peninsula showing the San Ignacio region. B, geological map of the San Ignacio region showing the sites IGM-loc 248 and IGMloc 265 (modified from Romero-Rojas et al., 1997).

(1957) and contains abundant marine biota (McLean et al., 1987; Schweitzer et al., 2005; Carreño and Smith, 2007). The Bateque Formation is discordantly covered by the Miocene marine sequence of whitish volcanoclastic sandstones interlayered with conglomeritic sandstones, marls, coquinas, and lutites that was named by MinaUhink $(1956,1957)$ as the San Ignacio Formation. This last geological unit shows some porphyry intrusions and is discordantly covered by continental strata composed of upper Miocene-lower Pliocene andesitic breccias, rhyolites, fluvial gravels and sandstones, polymictic conglomerates, and even basalt flows belonging to the Comondú Group (Beal, 1948; Romero-Rojas et al., 1997; Umhoefer et al., 2001; Carreño and Smith, 2007). Finally, the youngest rocks in the San Ignacio region are referred to as the Pleistocene basalts and volcanic breccia belonging to the Tres Vírgenes Group, as well as the Holocene alluvium and conglomerates (Wilson and Rocha-Moreno, 1955; Romero-Rojas et al., 1997).

\section{MATERIAL AND METHODS}

\section{Preparation Methods}

The rock matrix was removed from the fossils by alternating baths of $24 \times 24$ hours in clean water and Waller Solution. This solution consists of $71 \mathrm{~g}$ of sodium citrate $\left(\mathrm{Na}_{3} \mathrm{C}_{6} \mathrm{H}_{5} \mathrm{O}_{7}\right)$ and $8.5 \mathrm{~g}$ of sodium bicarbonate $\left(\mathrm{NaHCO}_{3}\right)$ per liter of distilled water; $20 \mathrm{~g}$ of sodium dithionite $\left(\mathrm{Na}_{2} \mathrm{~S}_{2} \mathrm{O}_{4}\right)$ was added just when the bath was applied (Maisey, 1991). Remaining limestone patches were removed with pin vices and needles under a binocular microscope. A last bath with sodium hydroxide $(\mathrm{NaOH})$ was given in order to remove dust particles. The specimens were photographed in the Colección Nacional de Paleontología, IGL, UNAM, using a Nikon D80 camera and a Nikon AF-S NIKKOR 18$140 \mathrm{~mm}$ lens. The microphotography was performed in the Laboratorio de Microscopía y Fotografía de la Biodiversidad (II), Instituto de Biología, UNAM, with the multi-focal macroscope Leica Z16 APO-A and using the Leica Application Suite software. 


\section{Institutional Abbreviations}

CAS; California Academy of Sciences, USA. IGM; Colección Nacional de Paleontología, Instituto de Geología, Universidad Nacional Autónoma de México, México. UCMP; Museum of Paleontology, University of California at Berkeley, USA. USNM; USA National Museum of Natural History, Smithsonian Institution.

\section{Comparative Material}

In the present research, the following specimens were studied with comparative purposes. Astrodapsis bajasurensis Squires and Demetrion, 1993 Holotype IGM 5926 and Paratypes IGM 5927-IGM 5933 from the middle Miocene near San Juanico, Baja California. Astrodapsis spatiosus Kew 1920, from the Miocene of Santa Margarita Formation, Scotts Valley, California. Astrodapsis merriami Anderson, 1905 Syntypes CAS 66758.01- CAS 66758.04 from the Miocene of California, USA. Vaquerosella andersoni (Twitchell, in Clark and Twitchell, 1915) USNM-PAL 165719, from the Early to Middle Miocene sediments of the Vaqueros Formation, in Kern County, California, USA. Vaquerosella coreyi Durham, 1955 Holotype UCMP 31712 from Temblor Formation, San Luis Obispo County, California, USA, and Paratype UCMP11027 from Vaqueros Formation, Orange County, California, USA. Vaquerosella durhami Adegoke, 1969 Holotype UCMP 36566 from Temblor Formation. Astrodapsis merriami Anderson, 1905 Syntypes CAS 66758.01 CAS 66758.03 from Temblor Formation, Kings County, California, USA. Vaquerosella norrisi (Pack, 1909) Holotype UCMP 11028 from Vaqueros Formation, Monterey County, California, USA. Scutella vaquerosensis Kew, 1920 Cotype UCMP 11403 from the Miocene of Monterey County, California, USA.

\section{Morphometric Data}

A table was constructed with 23 morphometric data (Figure 2). From the 21 specimens of Vaquerosella perrillatae sp. nov., their anatomical abbreviations are: $F_{a p}$, position of the apical system (from anterior edge of test to anterior edge of madreporic plate). $F_{p s}$, peristome position (anterior edge of test to anterior edge of peristome). $\mathrm{H}$, height of test (at apical system). $\mathrm{H}_{\mathrm{ap}}$, height of apical system. $I W_{1}$, width of interporiferous zone of ambulacrum I or $\mathrm{V}$ (at widest point). IW, width of interporiferous zone of ambulacrum III (at widest point). $\mathrm{IW}_{\mathrm{II}}$, width of interporiferous zone of ambulacrum II or IV (at widest point). L, maximum length of test. $L_{a p}$, length of apical system. $L_{1}$, length of ambulacrum I or $\mathrm{V}$ (from the corresponding ocular to the end of pore-series). $L_{\| l}$, length of ambulacrum II or IV (from the corresponding ocular to the end of pore-series). $\mathrm{L}_{\mathrm{III}}$, length of ambulacrum III (from the corresponding ocular to the end of pore series). $L_{\text {In }}$, length of lateral notch in ambulacrum I or $V$ (from junction of radial suture of interambulacrum 5 to a line drawn between the extension ends of the lobes adjacent to the notch). $L_{p n}$, length of posterior notch (from junction of interradial suture of interambulacrum 5 to a line drawn between the posterior extension ends of the lobes adjacent to the notch). $L_{p p}$, length of periproct. $L_{p s}$, length of peristome. $\mathrm{W}$, maximum width of test. $\mathrm{W}_{\mathrm{ap}}$, width of apical system. $W_{l}$, width of ambulacrum I or $V$ (at widest point). $\mathrm{W}_{\|}$, width of ambulacrum II or IV (at the widest point). $\mathrm{W}_{\mathrm{III}}$, width of ambulacrum III (at the widest point).

\section{Phylogenetic Analysis}

The relationships of the new Vaquerosella species described here are supported on the results of a phylogenetic analysis that includes the six valid species of this genus previously named. A data matrix (Table 1) was constructed using the program NEXUS data editor version 0.5.0 (Page, 2001); the matrix included nine taxa (seven species of Vaquerosella and two species of Astrodapsis included as outgroups) and 13 characters coded as follows:

1. Margin: 0 , rounded; 1 , with indentations at the perradial sutures.

2. Width of interambulacral zones on the oral side: 0 , interambulacral zones only about $20 \%$ of ambulacral width at ambitus; 1 , interambulacral zones at least $50 \%$ of ambulacral width at ambitus.

3. Disjunction in interambulacral zones: 0 , all five interambulacral zones strongly disjunct on oral surface, separated by enlarged first post-basicoronal ambulacral plates; 1 , interambulacral zones variably disjunct on oral surface but only posterior zone always widely separated.

4. Notches in the posterior ambulacra: 0, present; 1 , absent.

5. Opening of the paired ambulacra: 0, paired ambulacra wide open; 1 , ambulacra opening until onehalf the length, and then closing distally.

6. Projections in ambulacra 1, 4 and 5: 0, present; 1, absent.

7. Position of apical system: 0 , anterior; 1 , central.

8. Length of the petals: 0 , reaching the ambitus; 1 , more than halfway to the margin. 


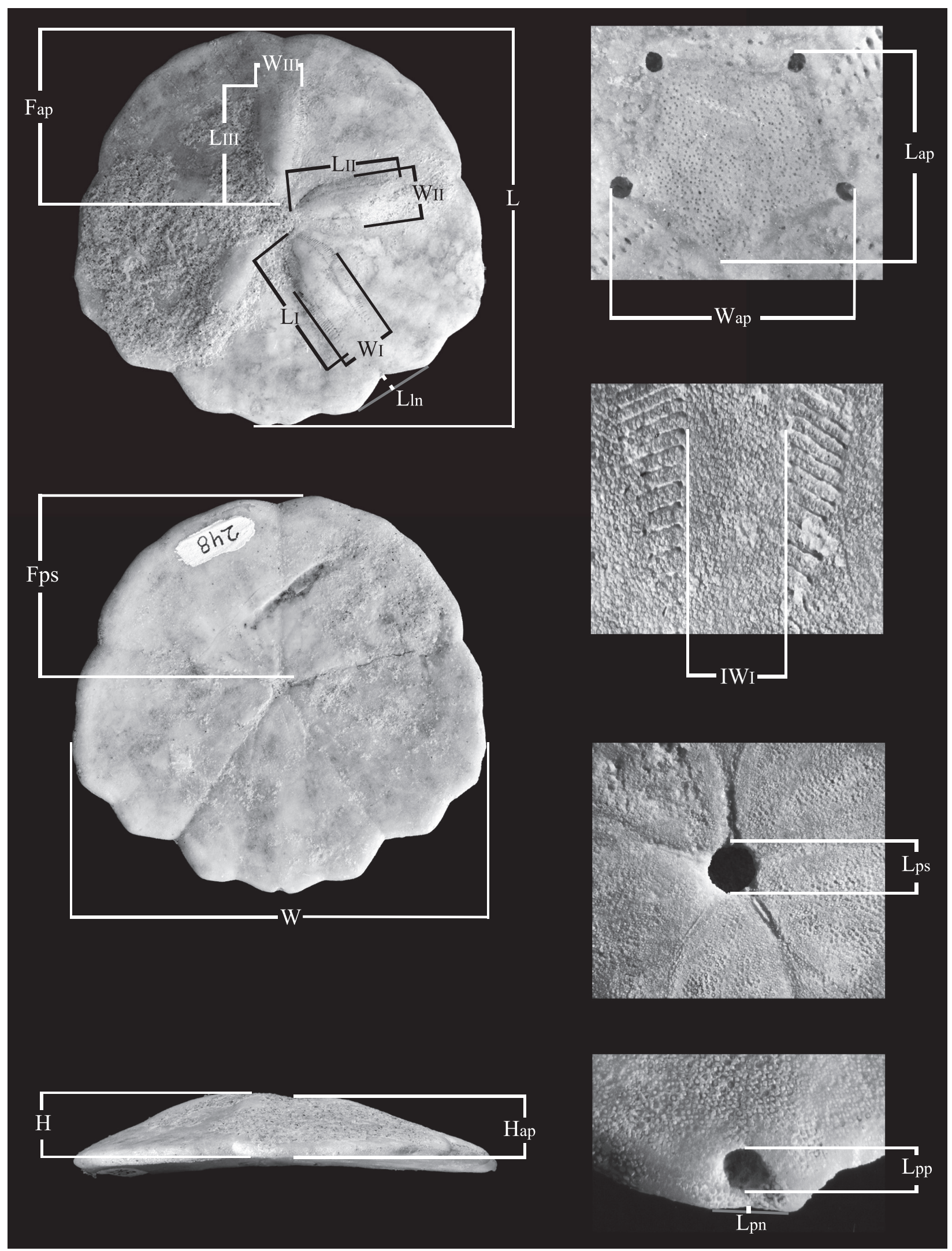

FIGURE 2. Morphometric schemes used in this study with the 23 distance measurements. 
TABLE 1. Data matrix analyzed to produce the Vaquerosella phylogenetic tree.

\begin{tabular}{llllllllllllll}
\hline & $\mathbf{1}$ & $\mathbf{2}$ & $\mathbf{3}$ & $\mathbf{4}$ & $\mathbf{5}$ & $\mathbf{6}$ & $\mathbf{7}$ & $\mathbf{8}$ & $\mathbf{9}$ & $\mathbf{1 0}$ & $\mathbf{1 1}$ & $\mathbf{1 2}$ & $\mathbf{1 3}$ \\
\hline A_bajasurensis & 1 & 1 & 0 & 0 & 0 & 1 & 1 & 1 & 0 & 1 & 0 & 1 & 1 \\
A_spatiosus & 1 & 1 & $?$ & 1 & 0 & 1 & 1 & 0 & 0 & 0 & 0 & 1 & 0 \\
$V$ _andersoni & 0 & 0 & $?$ & 0 & 0 & 1 & 0 & 1 & 1 & 0 & 1 & 0 & 1 \\
$V$ _coreyi & 1 & $?$ & $?$ & 0 & 0 & 0 & 0 & 1 & 1 & 1 & 1 & 1 & $?$ \\
$V \_$durhami & 0 & $?$ & $?$ & 1 & 0 & 1 & 1 & 1 & 1 & 1 & 1 & 0 & $?$ \\
$V \_$merriami & 0 & 0 & 0 & 1 & 1 & 1 & 1 & 1 & 1 & 1 & 1 & 0 & $?$ \\
$V \_$norrisi & 1 & $?$ & 0 & 0 & 0 & 0 & 0 & 1 & 1 & 1 & 1 & 0 & $?$ \\
$V \_$perrillatae sp. nov. & 1 & 1 & 0 & 0 & 0 & 0 & 1 & 1 & 0 & 1 & 1 & 1 & 0 \\
$V \_$vaquerosensis & 1 & 0 & 1 & 0 & 1 & 0 & 0 & 1 & 0 & 1 & 1 & 0 & $?$ \\
\hline
\end{tabular}

9. Petals rising: 0 , present; 1 , absent.

10. Interambulacra sunken: 0 , present; 1 , absent.

11. Apical system depressed: 0 , present; 1 , absent.

12. Opening of the frontal ambulacrum: 0 , distinctively more open than the paired petals; 1 , not distinctively more open than the paired petals.

13. Position of the apex: 0 , anterior; 1 , central.

The phylogenetic analysis was performed on the program PAUP version 4a165 (Swofford, 2002), employing a Heuristic Search protocol under default options; all characters were considering unordered and equally weighted; the optimization option of results considered here was the Accelerated Transformation Algorithm (ACCTRAN). Most parsimonious trees resulting from such protocol were included into analysis of strict consensus that generates the phylogenetic hypothesis of Vaquerosella described in this work. The Bremer and Bootstrap support values of the resulting tree were obtained under the same searching parameters; Bootstrap values were obtained from 1000 repetitions.

\section{SYSTEMATIC PALEONTOLOGY}

Class ECHINOIDEA Leske, 1778

Cohort IRREGULARIA Latreille, 1825

Order CLYPEASTEROIDA A. Agassiz, 1872

Suborder SCUTELLINA Haeckel, 1896

Infraorder SCUTELLIFORMES Haeckel, 1896

Family ECHINARACHNIIDAE Lambert, in Lambert and Thiery 1914

Genus VAQUEROSELLA Durham, 1955

Type species. Scutella andersoni Twitchell, in Clark and Twitchell, 1915 (Durham, 1955).

Diagnosis. (sensu Durham, 1955) Small to large, flattened; margin of test strongly indented at posterior ambulacra, less distinctly at other ambulacra. Apical system slightly anterior. Petals two-thirds to three-fourths length of radius; outer member of pore-pair moderately elongate. Periproct marginal. Peristome very slightly anterior; ambulacral food grooves simple, unbranched, at times indistinct. Basicoronal plates well developed; basicoronal interambulacral plates wider but not always higher than interambulacral plates. Post-basicoronal plates usually separated from basicoronal plates; three or four post-basicoronal interambulacral plates to column in paired interambulacra on oral surface; two post-basicoronal plates to a column in posterior interambulacrum on oral surface; five or six post-basicoronal plates to column in three anterior ambulacra on oral surface, sometimes only four plates in two posterior ambulacral columns. Interambulacra about two-thirds width of ambulacra at ambitus. The well-marked posterior ambulacral notching of the test and tendency to a width greater than length are characteristic.

Comments. Six nominal species have been described in the genus Vaquerosella (Figure 3): 1) the type species $V$. andersoni, 2) $V$. coreyi, 3) $V$. durhami, 4) V. merriami, 5) $V$. norrisi, and 6) $V$. vaquerosensis.

\section{Vaquerosella andersoni (Twitchell, 1915)}

Scutella andersoni Twitchell in Clark and Twitchell, 1915. Kew, 1920. Loel and Corey, 1932.

Echinarachnius andersoni Twitchell. Grant and Hertlein, 1938.

Vaquerosella andersoni. Adegoke, 1969.

Description (Twitchell, 1915). The test is small, ranging from less than one-half to slightly more than an inch in diameter. In marginal outline it is suboval to broadly subovate; broadest posteriorly, usually about as long as wide. The margin is thin, more so posteriorly than anteriorly, with rather pronounced notches opposite the posterior petals and sometimes with faintly defined notches opposite 


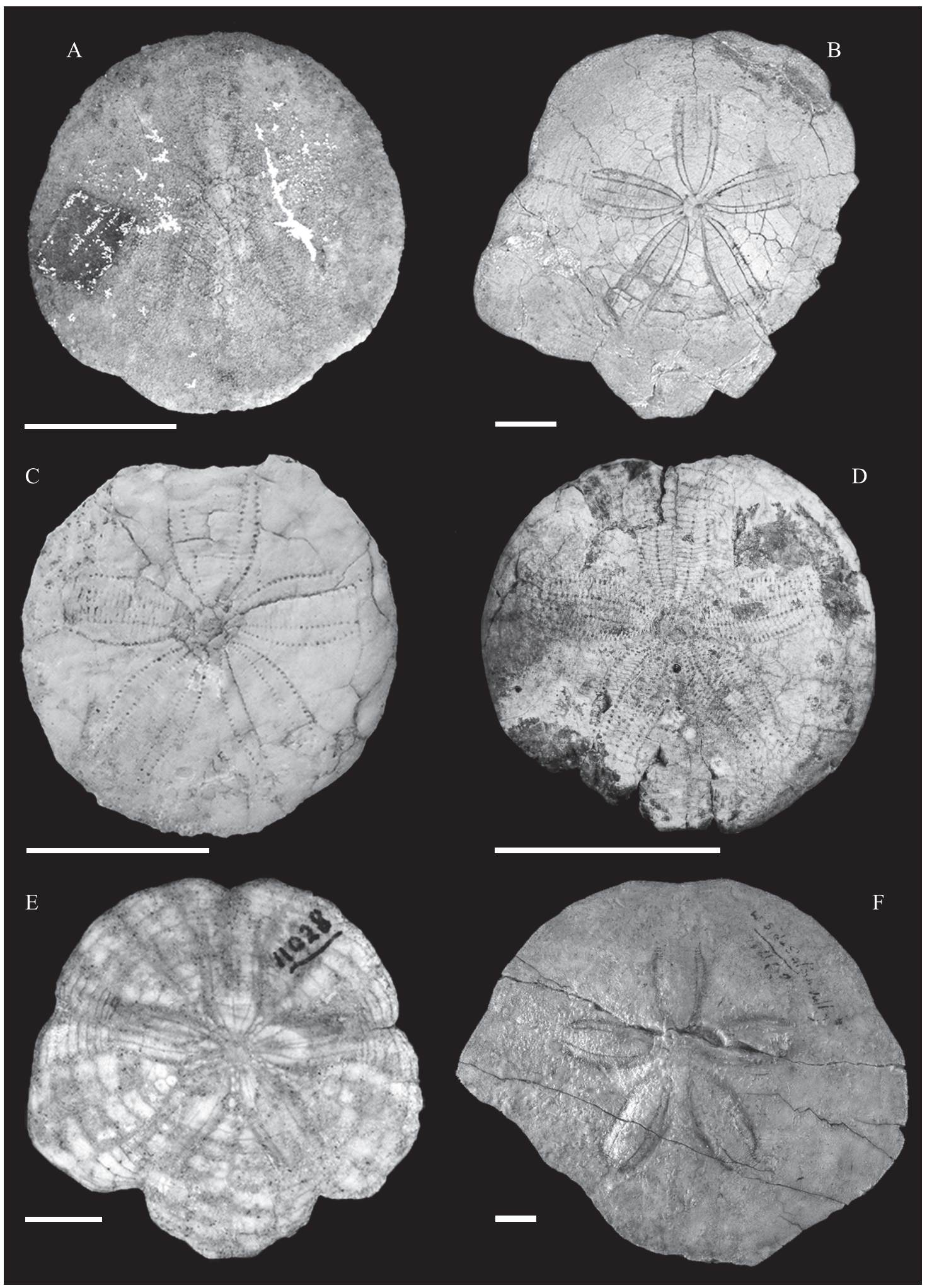

FIGURE 3. Nominal species in the genus Vaquerosella Durham, 1955. A, V. andersoni (Twitchell, in Clark and Twitchell, 1915) Holotype USNM PAL 165719A. B, V. coreyi Durham, 1955 Holotype UCMP 31712. C, V. durhami Adegoke, 1969 Holotype UCMP 36566. D, V. merriami (Anderson, 1905) Syntype CAS 66758-01. E, V. norrisi (Pack, 1909) Holotype UCMP 11028. F, V. vaquerosensis (Kew, 1920) paratype UCMP 11403. Images taken from their online collection databases (USNM PAL https://collections.nmnh.si.edu/search/paleo/; UCMP https://ucmpdb.berkeley.edu/) Scale bar equals $1 \mathrm{~cm}$. 
the anterior paired petals. The whole form is greatly depressed; the upper surface having a more or less well defined ridge extending along the longitudinal median line and involving the odd petal, the inner ends of the other petals, and the inner portion of the posterior interambulacrum; from the median ridge the surface slopes at first steeply then gradually away to the side edges. The under surface is slightly concave longitudinally. The apex is excentric anteriorly, at the highest point of the median ridge.

The ambulacral areas are rather narrow; the dorsal portions petaloid. The petals are moderate size, subelliptical, extending more than halfway to the margin, open at the ends, the odd petal more widely open than the others. The poriferous zones are relatively wide, though slightly less so than the interporiferous areas; pores oval, pairs of pores conjugated. The interambulacral areas are rather broad with the exception of the odd posterior area, which is narrow. The surface of the test is covered with small uniform tubercles. The apical system is decidedly excentric anteriorly, about coincident with the apex. There is a large, subcircular madreporite, four large genital pores, of which the anterior pair are somewhat nearer together than the posterior pair, and five small radial plates each perforated by a minute pore. The peristome is excentric anteriorly. The character of the ambulacral furrows cannot be made out on the specimens studied. The periproct is very small, circular, and supramarginal, almost marginal.

\section{Vaquerosella coreyi Durham, 1955}

Scutella norrisi Pack, 1909. Kew, 1920. Loel and Corey, 1932.

Description (Kew, 1920). Test large, with a width of test greater than the length. Marginal outline very irregular, due to the presence of broad deep marginal notches in the ambulacra, the two posterior ones being much greater than the anterior ones, giving the test the appearance of a maple leaf; the margin is also cut by slight indentations at the sutures between the ambulacral and interambulacral areas. Test very thin, flat, and rising but little to the apex, which coincides with the apical system. Apical system slightly anterior; madreporite large, pentagonal, with four genital pores situated at each of the corners, excepting the posterior one. Petaloid ambulacra about two-thirds the width of the interambulacra at the ambitus; symmetrical, of the same length, and extending about threefifths the distance to the margin; the posterior pair slightly narrower than the others. Rows of pores extend in divergent lines for about two-thirds the length of the petal, and then converge very slightly to the end, which gives the petal a nearly wideopen appearance; each poriferous area equal to about $1 / 3$ the width of the interporiferous area. Petals of small specimens are slightly tumid. Peristome small, subcircular and slightly posterior; with food grooves extending to the margin; indistinct branches are given off about two-thirds the distance to the edge of the test. Periproct small, round, and inframarginal, almost marginal.

$$
\text { Vaquerosella durhami Adegoke, } 1969
$$

Stutella merriami Pack, 1909.

Scutella andersoni Twitchell, 1915.

Echinarachnius andersoni. Grant and Hertlein, 1938.

Astrodapsis? merriami Anderson. Stewart, 1946.

Description (Adegoke, 1969). Small to mediumsized, with a circular and flattened test; generally similar in shape to Vaquerosella merriami (Anderson); margin slightly notched especially at extremities of posterior ambulacra, apex central, often raised slightly above the more flattened peripheral portions of the test; anterior as well as paired posterior petals open at extremities.

Vaquerosella merriami (Anderson, 1905)

Astrodapsis merriami Anderson, 1905.

Scutella merriami. Arnold, 1909.

Scutella (?) merriami. Clark and Twitchell, 1915.

Scutella andersoni Twitchell. Loel and Corey, 1932. Echinarachnius merriami. Grant and Hertlein, 1933.

Vaquerosella merriami. Adegoke, 1969.

Description (Clark and Twitchell, 1915). The marginal outline is usually circular, but sometimes longitudinal oval. The marginal notches are often hardly discernible. The test shows a decided tendency to form elevated stars on the upper surface. The petals extend from one-half to two-thirds the way to the margin. In some specimens the petals were practically flush with the surface and in some were slightly tumid. In some the poriferous zones of all the petals diverge continuously and are wide open at the ends, though the odd petal is somewhat more widely open than the rest; in others those of all but the odd petal is partly closed. The poriferous zones in the paired petals diverge for about half their length, then converge to a less degree so that, at their ends, they are only slightly bearer together than midway; those pores of the anterior petal diverging continuously to their ends, where they are far apart, the inner lines of pores forming a well-defined V.

Vaquerosella norrisi (Pack, 1909) 
Scutella norrisi Pack, 1909.

Description (Pack, 1909). Test sub-circular in general outline. With deep, broad, marginal notches in the edges of the ambulacral areas; the two posterior notches much deeper than the anterior ones, shaping the posterior end of the test into a prominent process. The test when viewed from above has a leaf-like appearance. Test flat with edges markedly thin. Apical system and test apex centrals. Mouth central, slightly sunken; food grooves poorly shown but little branched, continue from the mouth to the margin, entering the marginal notches. Periproct small, inframarginal. Petals strongly raised, extended about three-fourths the distance to the margin and not entirely closed at the ends.

Vaquerosella vaquerosensis (Kew, 1920).

Scutella vaquerosensis Kew, 1920.

Vaquerosella vaquerosensis. Durham, 1955.

Description (Kew, 1920). Large and thin, with outline undulating, truncated behind, and rounded anteriorly, with greater width immediately posterior to the center of the test; broadly notched in the paired ambulacral areas. Apical system slightly eccentric to the anterior; apex rising gently with the apical system or slightly anterior. Ambulacra much wider than the interambulacra at the ambitus; the anterior ambulacrum being twice as wide as the adjoining interambulacra. Petals broad, slightly elevated, and extending more than one-half the distance from the apical system to the ambitus, with the anterior pair somewhat shorter than the others. Anterior petaloid ambulacrum considerably wider than the rest, open distantly. Inner rows of pores of the paired petals converge slightly near the extremity; outer rows at first diverge and then converge to a greater degree, joining the inner rows at the ends of the petal. Interporiferous area about twice the width of each poriferous area. Peristome round and of comparatively small size. Food grooves well marked, straight, undivided, and extend to the edge of the test. Periproct round, small, and situated in a small notch in the margin.

Vaquerosella perrillatae sp. nov.

Figures 4-6; Table 2.

\section{zoobank.org/63CE8CF9-F1AC-4B54-B1C9-CA051527B929}

Etymology. The specific name honors Dra. María del Carmen Perrillat, former curator of the Colección Nacional de Paleontología, Instituto de Geología, UNAM, in gratitude for her efforts to preserve the Mexican paleontological heritage.

Type material. Holotype IGM 11463 (Figure 4). Paratypes IGM 11464 (Figure 5.A), IGM 11465
(Figure 5.B), IGM 11466 (Figure 5.C), IGM 11467 (Figure 5.D), IGM 11468 (Figure 5.E), IGM 11469 (Figure 5.F), and IGM 11470 (Figure 5.G). All specimens are from IGM-loc 248 except for IGM 11468 and IGM 11469 that were collected in IGM-loc 265. Additional material. IGM 11471 (Figure 6.A, 6.C, 6.E), IGM 11472 (Figure 6.B), IGM 11473 (Figure 6.D), IGM 11474 (Figure 6.F), IGM 11475 (Figure 7.A), IGM 11476 (Figure 7.B), IGM 11477, IGM 11478, IGM 11479, IGM 11480, IGM 11481, IGM 11482, and IGM 11483. All specimens are from IGM-loc 248.

Type locality. IGM-loc 248, the Arroyo San Ignacio site, San Ignacio Formation, coordinates $27^{\circ} 09^{\prime} 22.00^{\prime \prime} \mathrm{N}$ and $113^{\circ} 01^{\prime} 52.00 " \mathrm{~W}$, in the main drain of the San Ignacio River, Two paratypes are from the IGM-loc 265, Arroyo Nacho, located between the coordinates $27^{\circ} 09^{\prime} 22.00 " \mathrm{~N}$ and $113^{\circ} 01^{\prime} 52.00 " W$. Both sites are into Mulegé Municipality, Baja California Sur, Mexico.

Diagnosis. Test length and width nearly equal. Petal length three-fourths the distance from apical system to the ambitus. Ambitus with shallow indentations in each suture between columns of plates, resulting in a crenate margin. Anal notch small, slightly conspicuous, with soft projections on either side of posterior notch. Conspicuous notches at the ambulacra I and V, with soft projections on either side of lateral notch, acquiring a squared shape at the posterior margin.

Description. Test 46 to $77 \mathrm{~mm}$ in length (Table 2). Aboral surface slightly domed, oral surface slightly concave. Highest point of test $(7.2$ to $15.7 \mathrm{~mm})$ located at ambulacrum III, $34 \%$ of the length from the anterior edge. Outline slightly arrow-shaped from the aboral side, this due to the lateral notches in ambulacra I and V; with small notches in the other ambulacra. Test length almost equal to the width, with maximum width at interambulacra 1 and 4. Two very broad marginal indentations in ambulacra $\mathrm{I}$ and $\mathrm{V}$, opening at an angle of about $120^{\circ}$. Very shallow anal notch, almost inconspicuous (Figures 4-5).

Apical system monobasal, star-shaped, at 40$50 \% \mathrm{~L}$ from the anterior edge of test; with numerous hydropores scattered over madreporic plate; four gonopores, one in each paired interambulacra and located at the suture between the madreporic plate and the first adapical plates of the interambulacral column (Figure 6A).

Ambulacra petaloid, all approximately same length (Figure 6E). Ambulacra I and $\mathrm{V} 75 \%$ of corresponding test radius; ambulacra II and IV $70 \%$ of corresponding test radius. Paired ambulacra mod- 


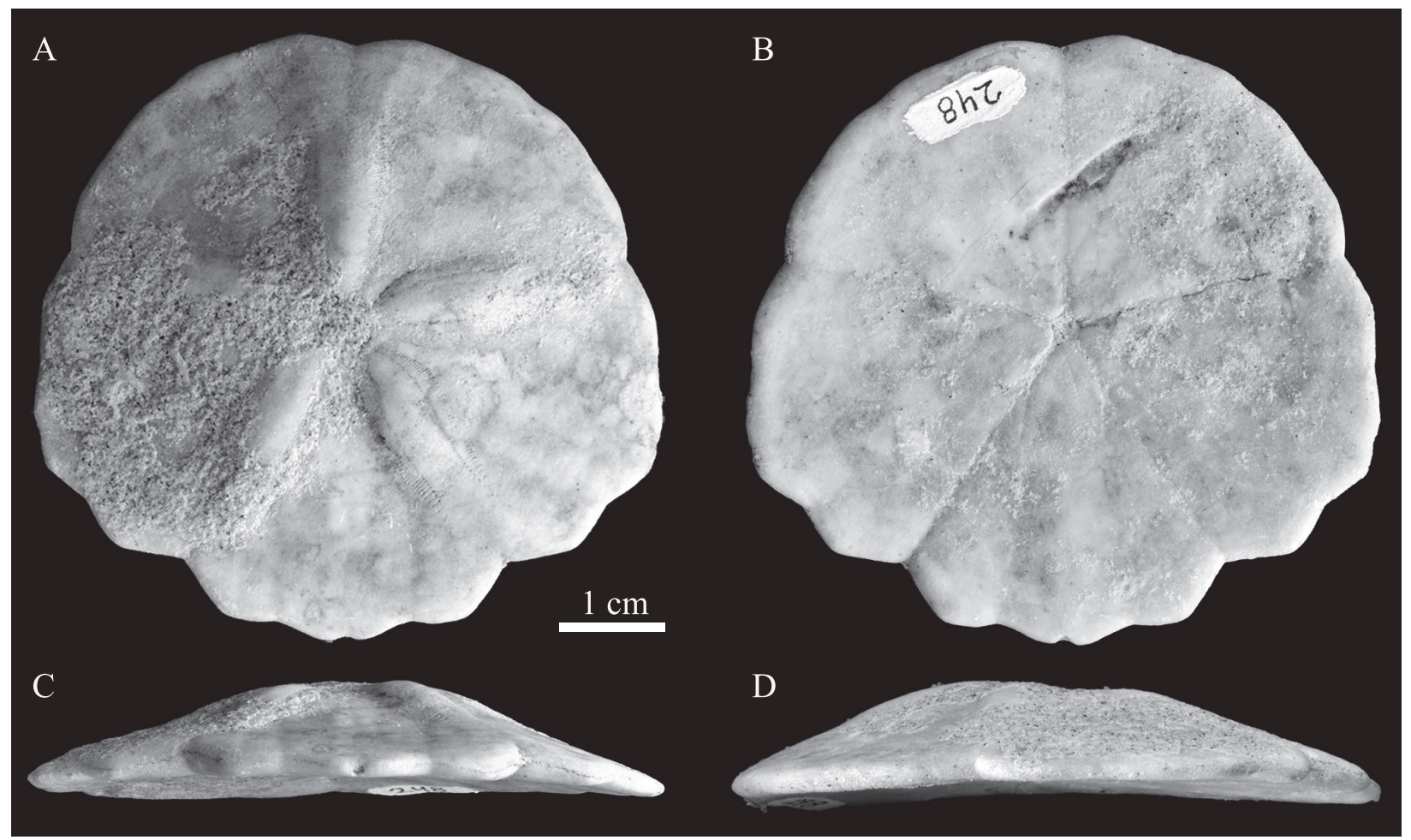

FIGURE 4. IGM 11463, holotype of Vaquerosella perrillatae sp. nov. A, aboral side. B, oral side. C, posterior side. D, left lateral side.

erately closed, maximum width at $45 \%$ of their length and close again to a $70 \%$ of their maximum width; with a few isolated pores outside petals. Anterior ambulacra petaloid III open, $75 \%$ of corresponding test radius, reaches its maximum width at the distal end (Figure 4A). Petals slightly elevated; petals almost closed distally, with four to six trailing tube feet at distal end of each column of respiratory tube feet (Figure 6E); not obviously lyrate, with outer pores tilted, with 6-7 tubercles in the poriferous zone (Figure 6B).

The ambulacral pores conjugated, inner pore slightly oval-shaped, outer pore slit-like, comprising almost one third of pore pair, apparently subdivided by stereom septae (Figure 6B). At ambitus, ambulacra greatly widened, length three times the width, curving strongly adapically to form test wall along each side of posterior notch. Ambulacral basicoronal plates all similar, narrow and straight with almost parallel radial sutures on each side (Figure 6D).

Interambulacra narrow near the apical system, containing paired, zig-zag plates, interambulacral plates widened at ambitus, length $3 x$ the width (Figure 7). Interambulacrum 5 not narrowing at ambitus but retaining same width as at end of petal.
On oral surface, three postbasicoronal plates in each half-interambulacrum in interambulacrum 5 , three or four in the other interambulacra (Figure 7). All interambulacral basicoronals discontinuous, separated from first postbasicoronals by adjacent first ambulacral postbasicoronals, which are wider in interambulacrum 5 (Figure 7B).

Peristome circular, relatively small $(4-8 \%$ of $\mathrm{L}$ ), anterior edge of peristome $45-50 \% \mathrm{~L}$ from the anterior edge of test, with distinct perradial process in each ambulacrum extending into peristome, beyond slight bulge containing sphaeridium (Figure 6). Anterior edge of peristome $54 \%$ TL from anterior edge of test. Food grooves well developed, restricted to oral surface, with no visible bifurcation near distal ends of ambulacral basicoronal plates. No significant depressions along perradial sutures on oral surface, no evidence of pressure drainage channels (Figure 6B).

Periproct small $(0.7-2 \% \mathrm{~L})$, between third and fourth postbasicoronal interambulacral plates; usually on posterior margin but sometimes on oral side (Figure 4B). Aboral tuberculation nearly homogeneous, with discernible enlargement of tubercles in oral interambulacral regions. Tube foot pores visible in food grooves. 


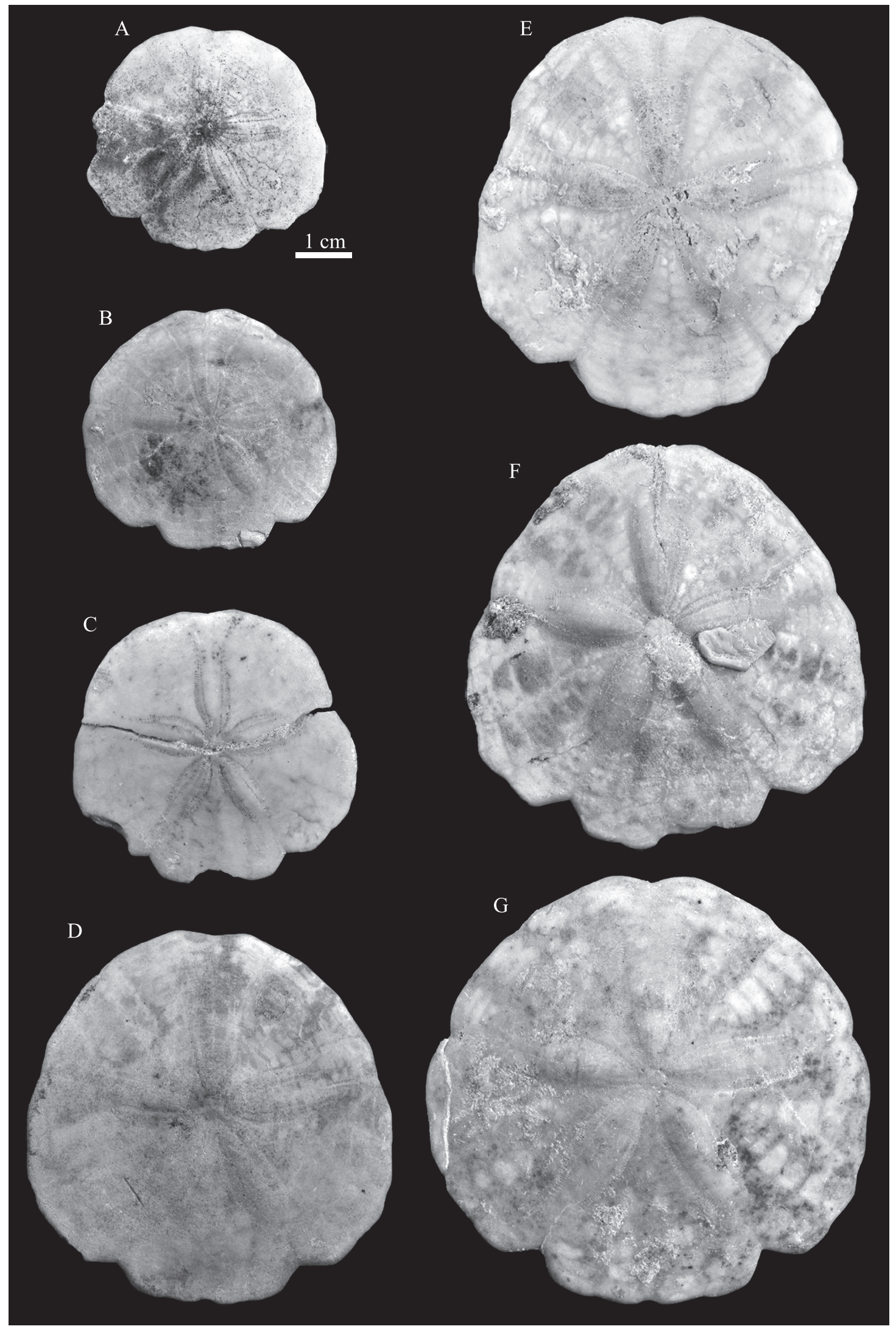

FIGURE 5. Paratypes of Vaquerosella perrillatae sp. nov. A, IGM 11464. B, IGM 11465. C, IGM 11466. D, IGM 11467. E, IGM 11468. F, IGM 11469. G, IGM 11470. 

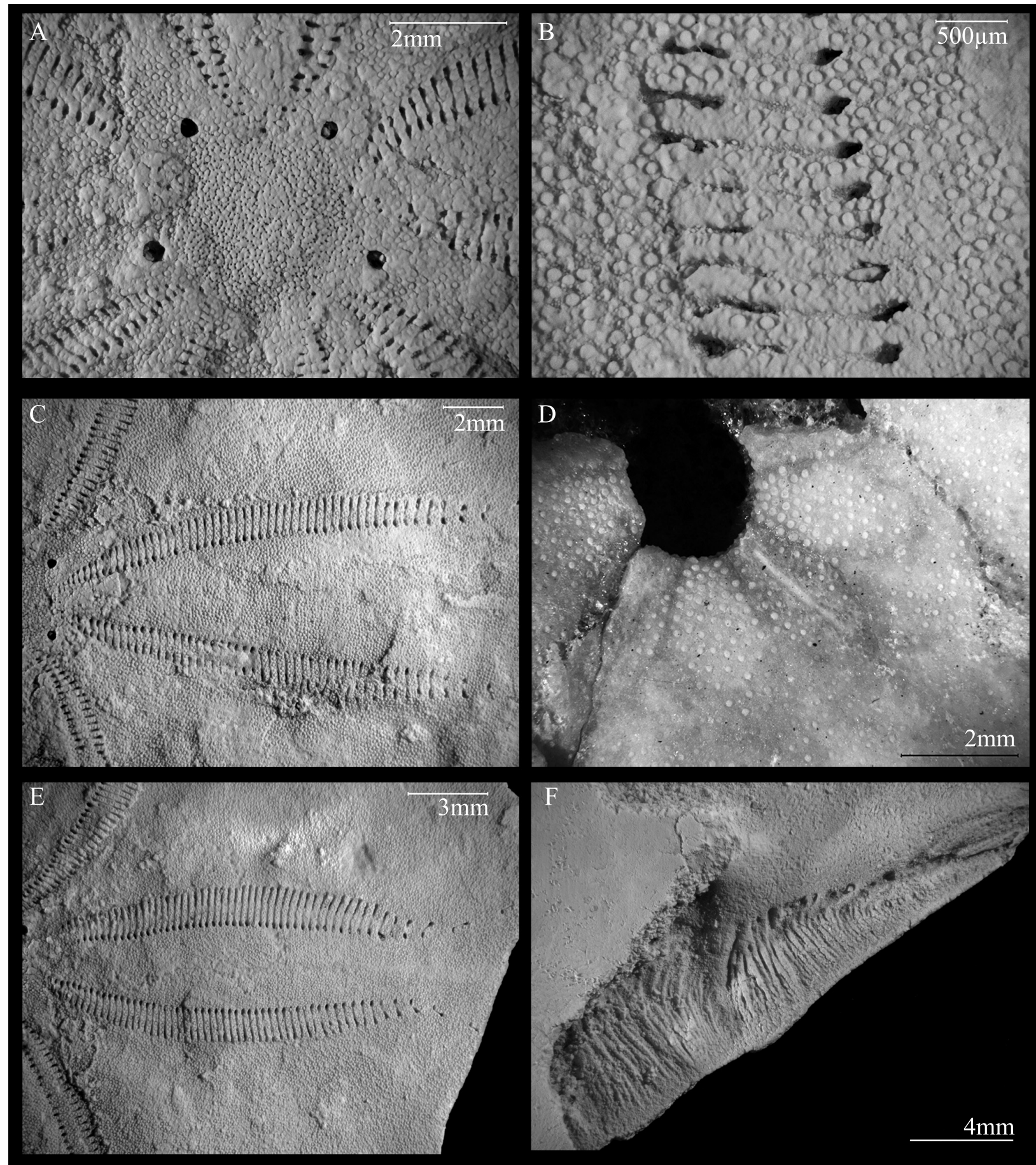

FIGURE 6. Multi-focal macroscope images of Vaquerosella perrillatae sp. nov. A, Apical system monobasal in IGM 11471. B, Conjugated pairs of pores in IGM 11472. C, Frontal ambulacrum in in IGM 11471. D, Ambulacrum IV in IGM 11473. E, Peristome with basicoronal plates in IGM 11471. F, internal support developed as concentric bars. 
TABLE 2. Morphometric data $(\mathrm{mm})$ of the specimens of Vaquerosella perrillatae sp. nov. See Anatomical abbreviations in Material and Methods. IGM, catalogue number. IGM-loc locality number.

\begin{tabular}{|c|c|c|c|c|c|c|c|c|c|c|c|c|c|c|c|c|c|c|c|c|c|}
\hline IGM & L & $\mathbf{W}$ & H & $\mathrm{L}_{p n}$ & $L_{\text {ln }}$ & $\mathrm{L}_{\mathrm{ap}}$ & $\mathbf{W}_{\text {ap }}$ & $\mathbf{H}_{\mathrm{ap}}$ & $F_{\text {ap }}$ & $\mathrm{L}_{\mathbf{I}}$ & $w_{1}$ & $\mathrm{IW}_{\mathrm{I}}$ & $\mathrm{L}_{\text {II }}$ & $\mathbf{W}_{\mathrm{II}}$ & $\mathrm{IW}_{\mathrm{II}}$ & $\mathrm{L}_{\text {III }}$ & $\mathbf{W}_{\text {III }}$ & $\mathrm{IW}_{\text {III }}$ & $\mathrm{L}_{\mathrm{ps}}$ & $F_{p s}$ & $\mathrm{~L}_{p p}$ \\
\hline 11463 & 58.4 & 61.2 & 10.8 & 0.4 & 2.6 & - & - & 10.6 & 27.3 & 17.7 & 8.1 & 4.4 & 18.0 & 7.9 & 4.3 & 18.5 & 8.5 & 5.5 & 2.2 & 26.8 & 0.7 \\
\hline 11464 & 46.0 & 48.3 & 10.1 & 0.5 & 1.8 & 2.7 & 3.1 & 7.5 & 21.6 & 15.5 & 6.3 & 2.8 & 15.1 & 6.3 & 2.7 & 15.1 & 7.1 & 4.0 & 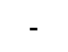 & 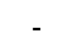 & 0.5 \\
\hline 465 & 46.9 & 50.2 & 11.0 & 0.5 & 2.6 & 2.4 & 3.0 & 9.4 & 22.4 & 15.5 & 6.1 & 3.1 & 15.2 & 5.8 & 3.2 & 14.9 & 6.5 & 4.1 & 2.3 & 22.5 & 0.7 \\
\hline 466 & 49.1 & 50.3 & 7.9 & - & 2.5 & - & - & - & 24.0 & 14.2 & 5.6 & 2.7 & 13.8 & & 2.9 & 16.5 & 6.6 & 3.8 & 3.5 & 3.4 & - \\
\hline 11467 & 66.6 & 66.2 & 9.9 & 1.1 & 2.4 & 3.5 & 4.4 & 7.9 & 29.8 & 21.4 & 9.3 & 4.7 & 20.4 & 8.5 & 4.5 & 21.8 & 8.9 & 6.7 & 2.8 & 33.0 & 0.5 \\
\hline 11468 & 77.6 & 77.0 & 15.7 & 2.5 & 4.2 & 4.1 & 4.5 & 13.6 & 32.5 & 25.0 & 9.4 & 6.3 & 20.5 & 11.1 & 6.0 & 23.0 & 10.5 & 7.5 & 3.1 & 36.0 & 1.0 \\
\hline 11469 & 77.5 & - & 13.0 & 1.0 & 4.8 & 3.6 & 4.2 & 12.7 & 31.7 & 23.9 & 8.8 & 4.5 & 20.8 & 9.4 & 5.4 & 24.6 & 9.1 & 5.4 & & & 0.7 \\
\hline 11470 & 74.5 & 77.4 & 14.0 & 1.1 & 4.7 & 3.7 & 4.3 & 12.5 & 32.0 & 24.6 & 10.3 & 6.6 & 24.2 & 9.2 & 5.1 & 25.0 & 10.5 & 9.3 & 2.7 & 34.2 & 1.0 \\
\hline & - & - & 12.6 & - & - & 3.6 & 4.1 & 10.2 & 23.5 & 10.5 & 5.6 & 23.4 & 10.0 & 10.2 & 5.5 & 20.2 & 10.2 & 6.8 & 3.7 & - & - \\
\hline 11472 & - & - & - & - & - & - & - & - & - & 15.3 & 6.3 & 2.7 & 15.5 & 6.3 & 2.9 & - & . & - & - & - & - \\
\hline 11473 & 42.9 & 8.5 & 0 & 2.3 & 2.7 & 2.9 & 7.6 & - & 13.3 & 5.2 & 2.6 & 12.2 & 6.1 & 2.9 & 12.0 & 5.8 & 3.2 & 2.4 & - & 0.9 & - \\
\hline 11474 & - & - & - & - & - & - & - & - & - & - & - & - & - & 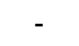 & - & - & - & - & - & - & 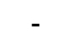 \\
\hline 11475 & 47.8 & 49.3 & - & - & 2.5 & - & - & 5.2 & 20.7 & 13.4 & 6.5 & 3.6 & 12.2 & 6.8 & 2.9 & - & - & - & 2.5 & 21.6 & - \\
\hline 11476 & 51.9 & - & 9.6 & 0.8 & 2.8 & - & - & 9.0 & - & 16.5 & 8.4 & 3.6 & 17.7 & 7.2 & 3.6 & - & 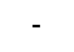 & - & 1.9 & 24.4 & 0.7 \\
\hline 11477 & 49.9 & 52.2 & 7.2 & 0.0 & & 3.1 & 3.0 & 7.0 & 21.9 & 17.4 & 6.9 & 3.3 & 15.6 & 6.2 & 2.9 & 16.5 & 6.8 & 3.8 & 2.3 & 23.6 & 1.0 \\
\hline 11478 & 61.2 & 64.2 & - & 1.4 & 2.8 & - & - & - & - & 20.3 & 6.6 & 3.5 & 19.9 & 7.1 & 3.5 & 21.4 & 8.5 & 5.8 & 2.3 & 30.9 & 1.3 \\
\hline 11479 & 76.9 & 71.3 & 12.0 & 1.1 & 2.8 & 3.6 & 3.9 & 11.6 & 36.0 & - & 9.8 & 5.2 & - & 10.3 & 4.4 & - & 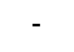 & - & 3.5 & 35.7 & 1.1 \\
\hline 11480 & 59.0 & 61.4 & 10.0 & - & 3.0 & - & - & 8.3 & - & - & 8.0 & 4.3 & - & 7.4 & 3.5 & - & 8.9 & 6.0 & - & - & - \\
\hline 11481 & 59.6 & - & 9.8 & 0.8 & 3.4 & 3.6 & 4.7 & 8.6 & 26.3 & 19.6 & 7.8 & 3.9 & 19.2 & 7.0 & 3.6 & 19.5 & 7.8 & 5.3 & 3.3 & 27.1 & 0.8 \\
\hline 11482 & 46.0 & - & 7.4 & - & - & 2.8 & 3.5 & 7.0 & 22.2 & 13.5 & 5.6 & 3.0 & 14.7 & 6.0 & 2.7 & 15.6 & 5.9 & 3.1 & 3.8 & 21.1 & 0.9 \\
\hline 11483 & 56.8 & - & 7.8 & 0.5 & 1.7 & 3.1 & 3.9 & 6.8 & 24.2 & 17.9 & 6.2 & 3.4 & 16.3 & 6.5 & 3.8 & 16.7 & 7.0 & 4.8 & 2.3 & 26.9 & 0.5 \\
\hline
\end{tabular}

Occurrence. IGM-loc 248 and IGM-loc 265, San Ignacio Formation, Mulegé, Baja California Sur, Mexico (Figure 1; Table 2).

\section{Key for the Nominal Species of Genus Vaquerosella}

1. Test with a rounded ambitus, with no notches ...2

- Test with postero-lateral notches, at the plates in ambulacra $\mathrm{I}$ and $\mathrm{V} \ldots \ldots \ldots \ldots \ldots$

2. Ambulacra wide open, specially the frontal ambulacrum . . . . . . . . . . . . . . . V. durhami

- Ambulacra opening until one-half the length, and then closing distally ........... merriami

3. Slight postero-lateral notches at the ambulacra I and $\mathrm{V}$; ambitus rounded. . . . . . . . V. andersoni

- Postero-lateral notches at the ambulacra I and V; ambitus with indentations at the perradial sutures. With projections in ambulacra 1,4 and $5 \ldots 4$

4. Enlarged interambulacra 1, 4 and $5 \geq 2 x$ the length of ambulacrum I or V; this due to large projections at the interambulacra, giving the ambitus a stellate shape................ 5
- Enlarged interambulacra 1, 4 and 5, <2x the length of ambulacrum I or $\mathrm{V} \ldots \ldots \ldots 6$

5. Both frontal and paired petals open at the distal end $\ldots \ldots \ldots \ldots \ldots \ldots \ldots$. coreyi

- Frontal petal open but the paired petals closed at the distal end . . . . . . . . vaquerosensis

6. An almost triangular posterior margin due to deep notches at the posterior ambulacra and the projection of interambulacrum $5 \ldots \ldots \ldots$. . . norrisi

- A squared shape at the posterior margin, due to shallow posterior notches and two small projections besides the periproct $\ldots . . . V$. perrillatae

\section{DISCUSSION}

\section{Phylogenetic Relationships}

The phylogenetic Heuristic Search performed in this study generated four equally parsimonious trees with a length of 20 steps each, Consistency Index of 0.65 and Homoplasy Index of 0.35. All these trees were included into a Strict Consensus Analysis that results in the single phylogenetic tree, 

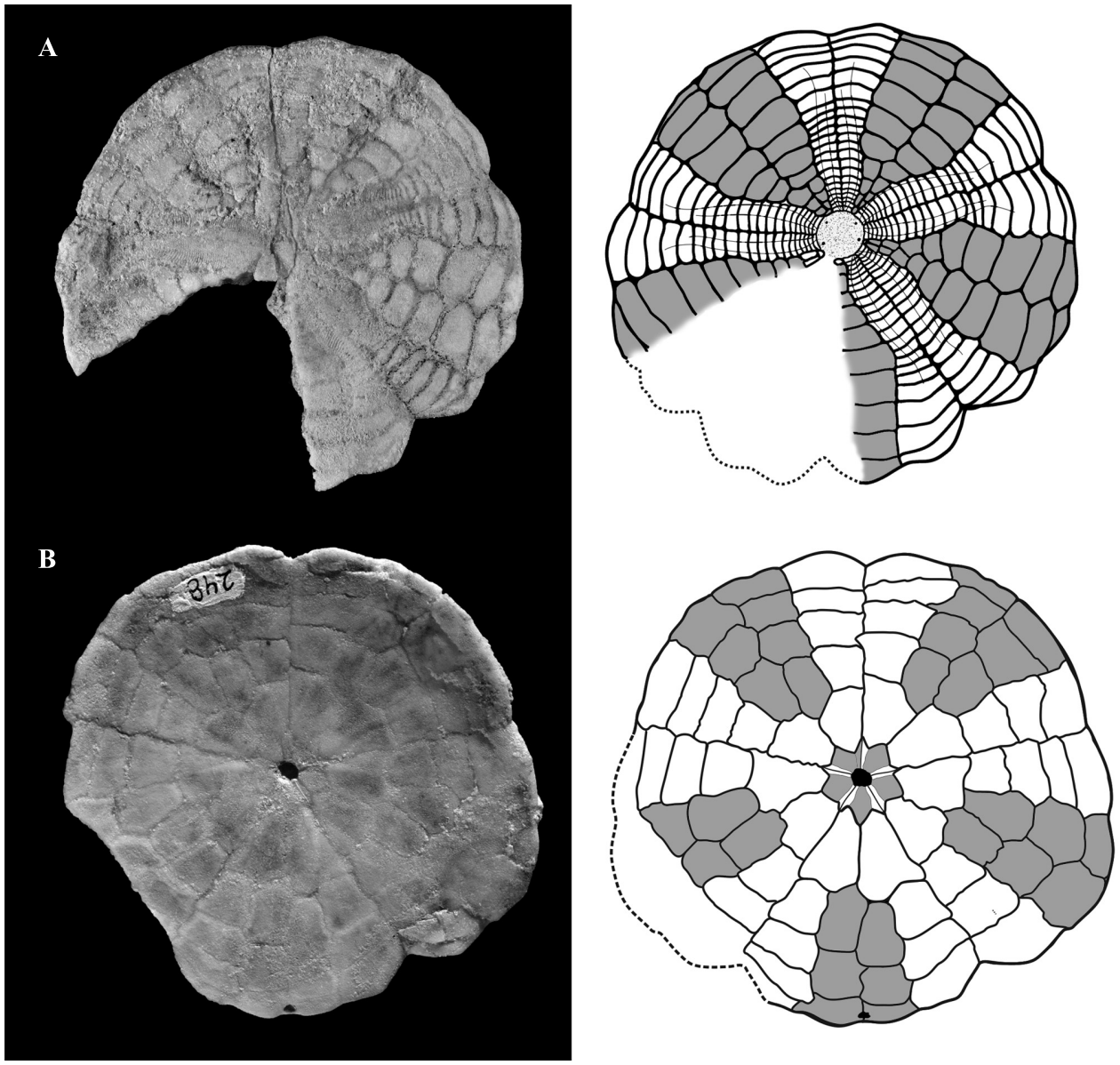

FIGURE 7. Plates arrangement of Vaquerosella perrillatae sp. nov. A, Plates on the aboral side in IGM-11475. B, plates on the oral side in IGM 11476 (interambulacral plates in gray).

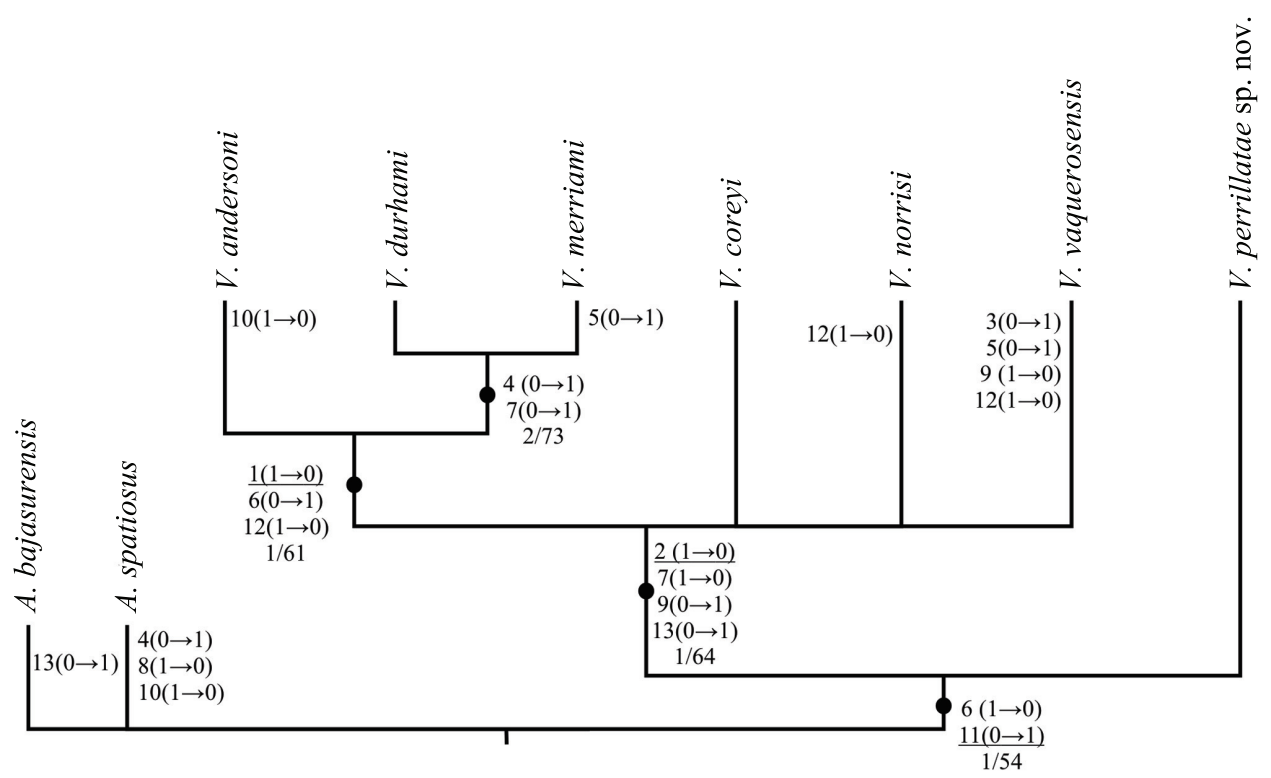

FIGURE 8. Phylogenetic hypothesis of the genus Vaquerosella obtained in this work. Nodes and terminal branches show the supporting characters and the respective changes on the states of characters [character (original state $\rightarrow$ final state)], Bremmer and Bootstrap supports values are shown near to each node [Bremmer/Bootstrap]. 
which here shows the interrelationships of Vaquerosella species (Figure 8). Although the Bremmer and Boostrap support values of this resulting tree seem low, with ranges of 1 to 2 and 54 to $73 \%$, respectively; our hypothesis includes three synapomorphies supporting its topology.

The genus Vaquerosella, including $V$. perrillatae, constitute a natural group supported on a single synapomorphy, apical system depressed, and one homoplasy, projections in ambulacra 1, 4, and 5 present (characters $11-1$ and 6-0, respectively, in Figure 8). The group of Vaquerosella less $V$. perrillatae is supported on one synapomorphy, interambulacral zones only about $20 \%$ of ambulacral width at ambitus, and three homoplasies that include anterior apical system, petals rising, and apex anterior (characters 2-0 plus 7-0, 9-0, and 13-1, respectively, in Figure 8). At the same way, the group constituted as Vaquerosella andersoni $+(V$. durhami + V. merriami) is supported on a single synapomorphy, margin rounded, and two homoplasies, projections in ambulacra 1, 4, and 5 present, and frontal ambulacrum distinctively more open than the paired petals (1-0 plus 6-1 and 12-0, respectively, in Figure 8). Finally, the most derived group of this genus, consisting of $V$. durhami and $V$. merriami, is supported only on two homoplasies, notches in the posterior ambulacra present, and anterior apical system (4-1 and 7-1, respectively, in Figure 8).

Although the goal of the present analysis was only partially achieved because the interrelationships of $V$. coreyi, $V$. norrisi, and $V$. vaquerosensis are unresolved; this study is the first effort to recognize the phylogeny of Vaquerosella. Our hypothesis is noticeable due the position taken by the new species described here, Vaquerosella perrillatae, as the most basal member of this genus, a fact that allows us to propose the Mexican origin of Vaquerosella, to the south and far from the Californian territory where most of its species have been identified (Figure 9).

Desirable additional efforts, including the thorough anatomical revision of all the Vaquerosella species and its echinarachnid allies, will be culminated on future hypotheses, more robust and inclusive that allows this possibility.

\section{Additional Comments}

Here, we present a new clypeasteroid species with pores arranged as bands across plates as well as along sutures; sphaeridia enclosed within plate; interambulacral zones remaining biserial to apex (Figure 4A); internal supports developed as con-

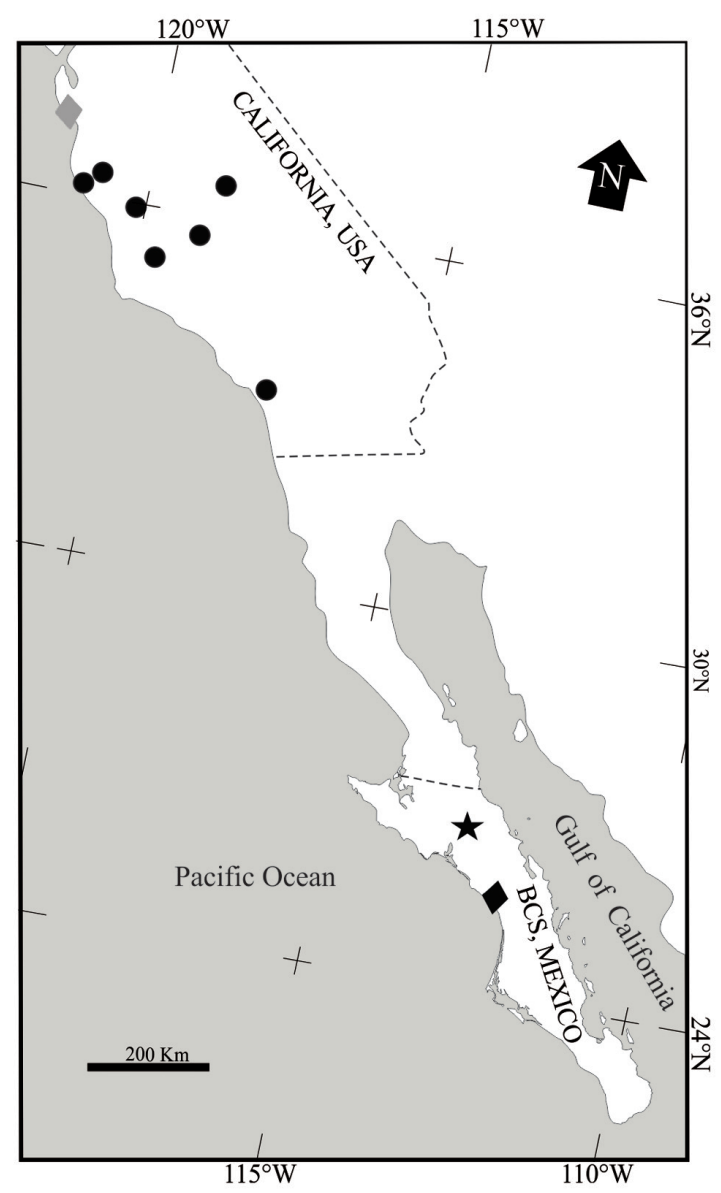

FIGURE 9. Distribution of the specimens included in the phylogenetic analysis. Astrodapsis spatiosus, Santa Margarita Formation; Astrodapsis bajasurensis, Isidro Formation; $\star$ Vaquerosella perrillatae sp. nov., San Ignacio Formation; Vaquerosella reports along Shibiwaka, Temblor and Vaqueros Formation.

centric bars (Figure 4F) and unbranched food grooves (Figure 2B). These characters allow us to determine its inclusion in the family Echinarachniidae sensu Smith and Kroh (2011).

As mentioned before, the family Echinarachniidae comprises seven genera: Astrodapsis, Echinarachnius, Faassia, Proescutella, Pseudastrodapsis, Scutellaster, and Vaquerosella. The position of the periproct and the continuity of the oral interambulacral plates are the main diagnostic characters between genera. The specimens here reported have an oral periproct located between the second and third postbasicoronal interambulacral plates; and five interambulacral zones strongly disjointed on the oral surface, separated by enlarged first post-basicoronal ambulacral plates. These characteristics coincide with the 
diagnosis of genus the Vaquerosella sensu Smith and Kroh (2011).

The type species of the genus, Vaquerosella andersoni, is distinguished from the others by the central apex and the interambulacra sunken.

When $V$. durhami was first described, Adegoke (1969) mentions the similarity between and $V$. merriami (Anderson) and distinguish them with the distal end of the petaloids; in V. merriami $(=V$. andersoni) only the anterior petals are open at the extremities, the paired petals being typically "closed", while in V. durhami, both paired anterior and posterior petals open at extremities.

When Durham (1955) stablished genus Vaquerosella, he named Scutella norrisi Pack described by Kew (1920) and Loel and Corey (1932) as Vaquerosella correyi Durham, 1955. Loel and Corey (1932) state that although it is very variable in shape, it is distinguished from $S$. vaquerosensis Kew by its open-end petals and more angular, more deeply notched and elongate outline.

Scutella vaquerosensis Kew, 1920, was mentioned by Durham (1955) as possible inclusion to genus Vaquerosella. Loel and Corey (1932) say that Scutella norrisi Pack can be distinguished from $S$. vaquerosensis Kew by its open-end petals and more angular, more deeply notched and elongate outline; in this study we observe that $V$. vaquerosensis is the only one species with interambulacral zones variably disjunct on oral surface but only posterior zone always widely separated.

Comparing Vaquerosella perrillatae sp. nov. with the species reported in the genus, $V$. andersoni is a small species, almost rounded, with small notches at the posterior ambulacra. Vaquerosella durhami presents ambulacra widely open, $V$. merriami with wider ambulacra but less open, both with a more rounded ambitus than $V$. perrillatae sp. nov. Vaquerosella coreyi presents a peculiar margin, with large projections at the interambulacra 1, 4, and 5 , acquiring a stellate shape.

Vaquerosella perrillatae sp. nov. resembles $V$. norrisi; both present a central apical system, marginal periproct, and ambulacra with the same length (three-fourths the distance from apical system to the ambitus), but they differ in the shape of the posterior margin; $V$. norrisi presents deeper notches at the posterior ambulacra, and the interambulacrum 5 projects, giving the test an almost triangular posterior margin, while in $V$. perrillatae sp. nov., the notches are shallower, and the periproct has only two small projections, giving it a squared shape at the posterior margin.

Although it is weak as a biostratigraphical element; the present discovery of fossils of Vaquerosella fossils in the San Ignacio Formation is important because the temporal range of this genus is limited to the Miocene. In this context, the presence Vaquerosella in the Pacific domains of Mexico and the USA represents additional evidence to establish possible corrections between the geological units exposed on both sides of the border. The discovery of Vaquerosella perrillatae in the San Ignacio Formation demonstrate that this geological unit is at least in part coeval with those marine deposits of the Vaqueros and Temblor formations, in California (USA), where numerous fossil echinarachnoids were previously recovered (Weaver et al., 1944; Stadum and Finger, 2016), including all other valid species of this genus (Clark and Twitchell, 1915; Durham, 1955; Adegoke, 1969; Anderson, 1905; Pack, 1909; among others).

\section{ACKNOWLEDGMENTS}

We are deeply indebted with S.P. Applegate† and L. Espinosa-Arrubarrena, who collected the specimens studied here. To R. Mooi and L. Villier for their guidance and support and to the anonymous reviewers for their comments and suggestions that improved significantly this manuscript. To V. Romero who kindly allowed access to the Colección Nacional de Paleontología of UNAM and the review of the type specimens referenced here. To A.A. Dineen, for her support with pictures and data of the UCMP specimens. To S. Guzman for her help with the multifocal microscopy, Laboratorio de Microscopía y Fotografía de la Biodiversidad (II), Instituto de Biología, UNAM. AMM was supported by the CONACYT-EPE 177483 fellowship. This work is supported by the UNAM DGAPA-PAPIIT Project IN 209017 "Vertebrados Marinos del Mesozoico y Cenozoico de México". 


\section{REFERENCES}

Adegoke, O.S. 1969. Stratigraphy and paleontology of the marine Neogene formations of the Coalinga region, California. University of California Press, Berkeley, California.

Agassiz, A. 1872. Revision of the Echini. Memoirs of the Museum of Comparative Zoology at Harvard College, 3:1-378. https://doi.org/10.5962/bhl.title.40080

Anderson, F.M. 1905. Stratigraphic study in the Mount Diablo Range of California. California Academy of Sciences Proceedings 3rd series, 2:156-248.

Arnold, R. 1909. Palaeontology of the Coalinga district, Fresno and Kings Counties. Bulletin of the United States Geological Survey, Virginia.

Beal, H.C. 1948. Reconnaissance of the geology and oil possibilities of Baja California, México. Geological Society of America, 31:1-133. https://doi.org/10.1130/MEM31-p1

Carreño, A.L. and Smith, J.T. 2007. Stratigraphy and correlation for the ancient Gulf of California and Baja California Peninsula, Mexico. Bulletin of American Paleontology, 317:1-146.

Clark, W.B. and Twitchell, M.W. 1915. The Mesozoic and Cenozoic Echinodermata of the United States. United States Geological Survey, Virginia. https://doi.org/10.5962/bhl.title.36384

Conrad, T.A. 1856. Description of three new genera, twenty-three new species middle Tertiary fossils from California and one from Texas. Proceedings of the Academy of Natural Sciences of Philadelphia, 8:312-316.

Cragin, F.W. 1895. A new Cretaceous genus of Clypeasteridae. American Journal of Geology, 55:90-91.

Durham, J.W. 1953. New name for Nipponaster Durham, 1952. Journal of Paleontology, 26:756756.

Durham, J.W. 1955. Classification of clypeasteroid echinoids. California University Publications in Geological Science, 31:73-198.

Durham, J.W. 1957. Notes on echinoids. Journal of Paleontology, 31:625-631.

Grant, U.S. and Hertlein, L.G. 1938. The West American Cenozoic Echinoidea (Vol. 2). University of California Press, Berkeley.

Gray, J.E. 1825. An attempt to divide the Echinida or sea eggs into natural families. Annals of Philosophy, 10:429-431.

Haeckel, E. 1896. Systematische Phylogenie der wirbellosen Thiere (Invertebrata), vol. 2. Georg Reimer Verlag, Berlin. https://doi.org/10.1515/9783111443935

Hall, C.A. 1962. Evolution of the echinoid genus Astrodapsis. University of California Publications in Geological Sciences, 40:47-180.

Kew, W.S.W. 1920. Cretaceous and Cenozoic Echinoidea of the Pacific coast of North America, Vol. 12. University of California Press, Berkeley.

Lamarck, J.B.M. 1816. Histoire naturelle des animaux sans vertèbres, Tome troisième. Deterville/Verdière, Paris. https://doi.org/10.1017/cbo9781139567473.005

Lambert, J. and Thiéry, P. 1914. Nomenclature Raisonnée des Echinides, 4:241-320.

Latreille, P.A. 1825. Familles naturelles du régne animal. Bailliere, Paris.

Leske, N.G. 1778. Jacobi Theodori Klein naturalis dispositio echinodermatum, edita et descriptionibus novisque inventis et synonomis auctorem aucta. GE Beer, Lipsiae. https:// doi.org/10.5962/bhl.title.11571

Loel, W. and Corey, W.H. 1932. The Vaqueros Formation, Lower Miocene of California, Paleontology. 1, Paleontology. University of California Publications, Bulletin of the Department of Geological Science, 22(3):31-410.

Maisey, J.G. 1991. Santana Fossils: An Illustrated Atlas, vol. 242. TFH Publications Incorporated, New Jersey.

Martínez-Melo, A. and Alvarado-Ortega, J. 2019. Expandiendo los límites de Abertella (Echinoidea: Clypeasteroida). XVI Congreso Nacional de Paleontología, septiembre 29 octubre 4, 2019, Chihuahua, México. Paleontología Mexicana, Número especial 5.

McLean, H., Hausback, B.P., and Knapp, J.H. 1987. The Geology of West-Central Baja California Sur, Mexico. United States Geological Survey Bulletin, 1579:1-16.

Mina-Uhink, F. 1956. Bosquejo geológico de la parte sur de la Península de Baja California. $20^{\circ}$ Congreso Geológico Internacional A-7, México Distrito Federal, 11-80.

Mina-Uhink, F. 1957. Bosquejo geológico del territorio sur de la Baja California. Boletín de la Asociación Mexicana de Geólogos Petroleros, 9(3):188-192. 
Morishita, A. 1953. On Sonic Neogene Echinoids from Nagano Prefecture, Japan. Memoirs of the College Unir, Kyoto, Series B, 20(4):217-224.

Mortensen, T. 1948. Report on the Echinoidea Collected by the United States Fisheries Steamer "Albatross" During the Philippine Expedition, 1907-1910, part 3: The Echinoneidae, Echinolampadidae, Clypeastridae, Arachnoididae, Laganidae, Fibulariidae, Urechinidae, Echinocorythidae, Palaeostomatidae, Micrasteridae, Palaeopneustidae, Hemiasteridae, and Spatangidae. United States Government Printing Office.

Nisiyama, S. and Hashimoto, W. 1950. A new Echinarachnius from the Tertiary of Hokkaido. Tohoku University Institute of Geology and Paleontology, Sendai Short Paper, 2:39-42.

Nisiyama, S. 1968. The echinoid fauna from Japan and adjacent regions part II. Palaeontological Society of Japan Special Papers, 13:1-491.

Pack, R.W. 1909. Notes on echinoids from the Tertiary of California. Notes on echinoids from the Tertiary of California. University of California Publications in Geological Sciences, 5:275-283.

Page, R.D.M. 2001. NDE: NEXUS data editor for Windows, Version 0.5. 0. University of Glasgow, Glasgow. http://mailman.nhm.ku.edu/pipermail/taxacom/2009-August/113618.html

Pomel, A. 1883. Classification méthodique et généra des échindes vivants et fossiles. Adolphe Jourdan, Alger. https://doi.org/10.5962/bhl.title.11272

Romero-Rojas, A., Maraver-Romero, D.A., Ávalos-Zermeño, A., and Aparicio-Cordero, E. 1997. Carta Geológico-Minera Santa Rosalia G12-1 Baja California Sur, Scale 1:250 000, + Explanation. Servicio Geológico Mexicano, Secretaría de Economía, México.

Schmidt, O.I. and Sinelnikova, V.N. 1971. On sea urchins of Kavran series (western Kamchatka). Doklady Akad, Nauk SSSR, 199(4):909-912.

Schweitzer, C.E., González-Barba, G., Feldmann, R.M., and Waugh, D.A. 2005. Decapoda (Thalassinidea and Paguroidea) from the Eocene Bateque and Tepetate formations, Baja California Sur, Mexico: systematics, cuticle microstructure, and paleoecology. Annals of Carnegie Museum, 74(4):275-293. https://doi.org/10.2992/00974463(2005)74[275:DTAPFT]2.0.CO;2

Smith, A.B. and Kroh, A. 2011. The Echinoid Directory. World Wide Web electronic publication. Accessed 23 October 2019. http://www.nhm.ac.uk/research-curation/projects/echinoiddirectory

Squires, R.L. and Demetrion, R.A. 1993. A new species of the clypeasteroid echinoid Astrodapsis from the Miocene Isidro Formation, Baja California Sur, Mexico. Journal of Paleontology, 67(2):258-263. https://doi.org/10.1017/S0022336000032182

Stadum, C.J. and Finger, K.L. 2016. Paleontology and stratigraphy of the Miocene Saddleback Valley Limestone, Orange County, southern California. Natural History Museum of Los Angeles County Contributions to Science, 524:31-49.

Stewart, R. 1946. Geology of the Reef Ridge, Coalinga District, California. United States Geology Survey, Professional Paper, 205-C:81-115. https://doi.org/10.3133/pp205c

Swofford, D.L. 2002. PAUP*. Phylogenetic Analysis Using Parsimony ("and Other Methods), 4.0 edn, Sinauer, Sunderland, MA.

Umhoefer, P.J., Dorsey, R.J., Willsey, S., Mayer, L., and Renne, P. 2001. Stratigraphy and geochronology of the Comondú Group near Loreto, Baja California Sur, Mexico. Sedimentary Geology, 144:125-147. https://doi.org/10.1016/S0037-0738(01)00138-5

Wagner, C.D. 1974. Fossil and Recent sand dollar echinoids of Alaska. Journal of Paleontology, 48:105-123.

Weaver, C.E., Beck, S., Bramlette, M.N., Carlson, S., Clark, B.L., Bruce, L., Dibblee, T.W., Durham, W., Ferguson, G.C., Forest, L.C., Grant, U.S., Hill, M., Kelley, F.R., Kleinpell, R.M., Kleinpell, W.D., Marks, J., Putnam, W.C., Schenck, H.G., Taliaferro, N.L., Thorup, R.R., Watson, E., and White, T. 1944. Correlation of the marine Cenozoic formations of Western North America. Bulletin of the Geological Society of America, 55:569-598. https://doi.org/ 10.1130/GSAB-55-569

Wilson, I.F. and Rocha-Moreno, V.S. 1955. Geology and mineral deposits of the Boleo Copper District, Baja California, Mexico. United States Geological Survey, Virginia. https://doi.org/ 10.3133/pp273 